\title{
Avaliação do Efeito do Complexo Osseína-Hidroxiapatita na Consolidação das Fraturas na Desnutrição Protéica: Estudo Experimental em Ratos
}

\author{
Effect of the Ossein-hydroxyapatite Complex on Fracture Consolidation Under Protein Malnutrition: \\ Experimental Study Using Rats
}

Wilson Galego Campos *

\section{RESUMO}

Foi realizado trabalho experimental com 40 ratos da raça Wistar, machos, para avaliar o efeito do complexo osseína-hidroxiapatita $(\mathrm{COH})$, na consolidação das fraturas, em animais submetidos a dieta protéica e dieta aprotéica, divididos em quatro grupos distribuídos aleatoriamente, que receberam ou não a medicação. Cada grupo com 10 animais foi assim constituído: grupo I, protéico sem $\mathrm{COH}$; grupo II, protéico com $\mathrm{COH}$; grupo III, aprotéico sem $\mathrm{COH}$; grupo IV, aprotéico com $\mathrm{COH}$. Procurou-se fazer fraturas semelhantes quanto ao traço e a localização em todos os grupos no $15^{\circ}$ dia, passando os grupos II e IV a receber a dose diária de $20 \mathrm{mg}$ do $\mathrm{COH}$, por gavagem. Todos os grupos foram submetidos à coleta de sangue no $1^{\circ}, 15^{\circ}$ e $43^{\circ}$ dia, que foi o dia da eutanásia dos animais. Além do controle de peso fez-se a dosagem de cálcio, fósforo, fosfatase alcalina, proteínas totais, albumina e osteocalcina. O membro fraturado foi desarticulado na articulação coxofemural, no $43^{\circ}$ dia, sendo submetido o calo ósseo à avaliação histológica, histomorfométrica, radiográfica e densitométrica e planimétrica. Concluiu-se, após análise estatística, que o $\mathrm{COH}$ não interferiu, de maneira significativa, na avaliação geral, na formação do calo ósseo dos animais nutridos e desnutridos. Entretanto mostrou interferência em alguns resultados como na dosagem de albumina e de fosfatase alcalina, na planimetria e no peso dos animais.

Descritores: Estudo Experimental, Consolidação Óssea, Complexo Osseína-Hidroxiapatita.

\section{SUMMARY}

Assessement of the effect of ossein-hidroxiapatite compound in the fracture healing under protein malnutrition: experimental essay in rats.

An experimental essay was carried out with 40 Wistar male rats to assess the effect of the ossein-hidroxiapatite compound $(\mathrm{OHC})$ in the fracture healing in animal under protein diet and no protein diet, which were divided into four groups, at random, which received or did not receive the compound. Each group with 10 animals, was divided into: group I, protein diet, without $\mathrm{OHC}$; group II, protein diet, with $\mathrm{OHC}$; group III, no protein diet, without $\mathrm{OHC}$; group $\mathrm{N}$, no protein diet, with $\mathrm{OHC}$. The fractures were made similarly as to the trace and site in all groups in the $15^{\text {th }}$ day, when groups II and IV started receiving a daily dose of $20 \mathrm{mg}$ of the $\mathrm{OHC}$, orally. Blood samples were drawn from all groups on the $1^{\text {st }}, 15^{\text {th }}$ and $43^{\text {rd }}$ days. The animals underwent euthanasia on the $43^{\text {rd }}$ day. Weight control as well as calcium, phosphorus, alkaline phosphatase total proteins, albumin, and osteocalcine were determined. The fractured limb was desarticulated in the hip joint on the $43^{\text {rd }}$ day, and the bone callus was submitted to histological, histomorphometric, radiographic, planimetric and densitometric examination. It was concluded, after statistical analysis, that the $\mathrm{OHC}$ did not interfere significantly, in general assessment in bone callus formation in malnutrition and nourished animals. However it showed significant interference in some results such as albumin and alkaline phosphatase blood samples, in the planimetry and weight of the animals.

Key words: Experimental Study, Osseous Consolidation, OsseinHidroxiapatite Compound 


\section{INTRODUÇÃO}

Drogas, tradicionalmente utilizadas, não têm sido objeto de estudos comparativos experimentais, atuais, para referendar a sua real validade e aprimorar a obtenção dos efeitos desejáveis.

A prevalência da desnutrição protéica, elevada em nosso meio, nociva ao tecido ósseo, merece estudos; a desnutrição deve ser considerada ao se ministrarem medicamentos que visam abreviar o período de consolidação das fraturas. O objetivo do trabalho é avaliar o efeito do complexo osseína-hidroxiapatita $(\mathrm{COH})$, experimentalmente, em ratos, machos, adultos, em fraturas provocadas nas tíbias de animais nutridos e desnutridos.

$\mathrm{O} \mathrm{COH}$ tem sido usado em ensaios clínicos nas deficiências minerais e osteoporose de humanos, além de ser citado como adjuvante na consolidação mais rápida de fraturas.

Foram analisados os comportamentos bioquímicos do cálcio, fósforo e fosfatase alcalina, além das proteínas totais e albumina. Igualmente o marcador bioquímico da formação óssea, a osteocalcina, foi dosada para se procurar estabelecer nos resultados de exame, correlações entre o $\mathrm{COH}$, desnutrição e consolidação óssea. Foram analisados também, através de avaliações ponderal, radiográfica, densitométrica, microscópica, histológica e histomorfométrica, os dados obtidos em análise estatística.

\section{MATERIAL E MÉTODOS}

Foram utilizados 40 ratos machos, albinus, de linhagem Wistar, com peso inicial variando de 250 a 400 gramas.

Os 40 animais foram aleatoriamente divididos em quatro grupos, assim distribuídos: Grupo I - dieta protéica sem $\mathrm{COH}$ (10 ratos); Grupo II - dieta protéica com COH (10 ratos); Grupo III - dieta aprotéica sem $\mathrm{COH}$ (10 ratos); Grupo IV - dieta aprotéica com $\mathrm{COH}$ (10 ratos).

Após duas semanas do início do trabalho, de acordo com as dietas estabelecidas, o $\mathrm{COH}$, na dose de $20 \mathrm{mg} / \mathrm{dia}$, oral, por gavagem, foi administrado aos grupos II e IV.

Foi feita colheita de sangue por punção intracardíaca sob anestesia geral no $1^{\circ}, 15^{\circ}$ e $43^{\circ}$ dia, para as análises bioquímicas. No $15^{\circ}$ dia todos os ratos foram submetidos a fratura fechada do terço médio da tíbia esquerda, por flexão manual, sob anestesia com éter etílico. Após quatro semanas da fratura todos os animais foram submetidos à eutanásia com super dosagem de éter etílico. Procedeu-se a desarticulação da articulação coxofemural do membro fraturado, para estudos radiográfico, planimétrico, densitométrico, histológico e histomorfométrico. Os dados obtidos das análises bioquímica, ponderal, radiográfica, densitométrica, microscópica e histomorfométrica foram submetidos à análise estatística, em nível de significância de 5\%, ou seja, os testes foram considerados significativos quando $p<0,05 \%$.

\section{INTRODUCTION}

Traditional drugs have not been focused by experimental, comparative and recent studies to establish their actual validity and improve the achievement of the wanted effects.

The high prevalence of proteic malnutrition in our environment causes harm to the bone tissue and deserves more study; malnutrition must be considered when drugs are administered to reduce the consolidation period of a fracture. The aim of this study was to experimentally evaluate the effect of the osseinhydroxyapatite complex (OHC) on male, adult, nourished and undernourished rats with fractures provoked in their tibias.

$\mathrm{OHC}$ has been clinically experimented as concerns mineral deficiency and osteoporosis in humans, besides being considered an adjuvant to promote faster fracture consolidation.

The biochemical behavior of calcium, phosphorus and alkaline phosphatase as well as total protein and albumine was observed. The bone formation biochemical marker, osteocalcin, was determined in order to establish correlations concerning $\mathrm{OHC}$, malnutrition and bone consolidation. After ponderal, radiographic, densitometric, microscopic, histological and hystomorphometric determinations the data from the statistical analysis were analyzed.

\section{MATERIAL AND METHOD}

Forty male, albinus, Wistar rats weighing initially 250-400 g were utilized in this study.

The forty animals were randomly allocated into four groups: Group I - proteic diet without OHC (10 rats); Group II - proteic diet with $\mathrm{OHC}$ (10 rats); Group III - non-proteic diet without OHC (10 rats); Group IV - non-proteic diet with OHC (10 rats).

After two weeks, $20 \mathrm{mg} /$ day $\mathrm{OHC}$ were orally administered to groups // and IV.

Blood was collected through intracardiac puncture under general anesthesia at days 1, 15 and 43 and submitted to biochemical analysis. In day 15, closed fracture in the left tibia middle third was produced, by manual flexure, under ethyl ether anesthesia. Four weeks after the fracture all the animals were sacrificed using an overdose of ethyl ether. The fractured limb was coxofemorally disarticulated and radiographic, planimetric, densitometric, histological and histomorphometric determinations were made. Data from the biochemical, ponderal, radiographic, densitometric, microscopic and histomorphometric analysis were submitted to statistical analysis, at the 5\% significance level; the tests were considered significant when $p$ $<0.05 \%$. 


\section{DISCUSSÃO}

A escolha do $\mathrm{COH}$ que tem componentes orgânicos importantes na consolidação das fraturas, aplicados a animais nutridos e desnutridos, permite a avaliação da importância destes fatores.

O rato Wistar, animal escolhido para o experimento, mostrou-se de extrema utilidade naárea de pesquisa pelas seguintes vantagens: a) fornece dados semelhantes aos verificados no esqueleto humano; b) é animal dócil; c) as fraturas são de rápida consolidação, dispensando imobilização ${ }^{10}$; d) as alterações ósseas podem ser facilmente analisadas 8,9 ; e) execução de fraturas experimentais semelhantes; f) formação do calo ósseo através de dietas estabelecidas ${ }^{4}$; e com substâncias hormonais, dentre as quais a calcitonina, conforme demonstrado por GUARNIERO ${ }^{5}$ et al. (1995).

A similaridade de fraturas, obtidas, preconizadas por URIST; McLEAN ${ }^{13}$ (1950), mostrou-se satisfatória, sendo possível detectar pequenas diferenças das fraturas, porém, a nosso ver, desnecessárias à criação de dispositivos mecânicos especiais para fazer a fratura. Optou-se por não utilizar materiais de osteossíntese no foco de fratura, para não aumentar a oportunidade de interferência na consolidação óssea pela presença desses materiais. O delineamento de estudo, casualizado em quatro grupos de dez, permitiu-se análise estatística consistente. A dieta aprotéica levou a alterações verificadas na análise dos valores de proteínas totais e albuminas e a desnutrição protéica assim obtida teve interferência direta na consolidação das fraturas, concordando com as observações de ${ }^{11,4}$. A eutanásia na $6^{a}$ semana mostrouse oportuna pelo sofrimento dos animais e por ser neste período o calo bem visível, ${ }^{1}$

Não se realizaram testes de mobilidade do foco de fratura, preconizado por HEARD ${ }^{6,7}$ et al. (1.982), por ser este teste dependente do operador. Não foram feitos estudos de resistência mecânica do calo, o que certamente enriqueceria o trabalho.

A anestesia dos animais mostrou ser eficiente com o éter etílico, porém devem ser considerados outros tipos de anestésicos que levam em conta possíveis interferências nos experimentos.

Observou-se efeito do $\mathrm{COH}$ nas dietas avaliadas aos $15^{\circ}$ e $43^{\circ}$ dias, após o início do estudo, sendo que os pesos médios dos grupos com a dieta protéica e dieta aprotéica diferiram significativamente $(p<0,0001)$. Na terceira avaliação observou-se efeito significativo da adição de $\mathrm{COH}$ somente na dieta aprotéica ( $p$ $=0,0104$ ).

$\mathrm{Na}$ análise das proteínas totais observou-se que houve efeito significativo somente das dietas na avaliação aos 43 dias ( $p<$ 0,0001 ). A dieta interferiu nos níveis médios de proteínas totais, o que não ocorreu com a adição do $\mathrm{COH}$.

A análise da albumina indicou que seus níveis médios mostraram a significância do efeito das dietas aos 43 dias ( $p=0,0003)$, e $o$ efeito da adição de $\mathrm{COH}$ foi também observado aos 43 dias ( $p=$ $0,0282)$, ocorrido somente na dieta aprotéica $(p=0,0094)$.

A osteocalcina sintetizada pelos osteoblastos é incorporada à matriz óssea, com pequena fração liberada na circulação, e serve

\section{DISCUSSION}

$\mathrm{OHC}$, administered to nourished and undernourished animals, has important organic components to consolidate fractures so the importance of these factors must be evaluated.

The Wistar rat is extremely useful in research for the following reasons: a) provides data similar to those observed in the human skeleton; b) is a manageable animal; c) its fracture show fast consolidation, dispensing immobilization, OTTO et al. (1995); d) bone alterations can be easily analyzed (LI et al., 1990; MAEDA et al., 1993); e) similar experimental fractures can be obtained; f) formation of bone callus with established diets (GUARNIERO, 1987) and hormonal substances, among them the calcitonin, according to GUARNIERO et al. (1995).

The similarity of the fractures, preconized by URIST and MCLEAN (1950), was satisfactory, and it was possible to detect small differences in the fractures; however, under our point of view, the elaboration of special mechanical devices to make the fracture is not necessary. Osteosynthesis materials were not used in the fracture focus, since the presence of these materials could interfere in bone consolidation. The design of the study, with four groups with ten pacients each provided a consistent statistical analysis. The non-proteic diet caused alterations pointed out by the total protein and albumin values; the protein malnutrition thus produced exerted direct interference in the fracture consolidation, in agreement with PARK (1964) and GUARNIERO (1987) observations. Euthanasia after six weeks was convenient due to the animals suffering and because in this occasion the callus was very visible, (ARO, 1985).

Tests of the fracture focus mobility according to HEARD et al. (1982) were not effected because they are operator dependent. Mechanical resistance studies of the callus were not made, but this would certainly improve the quality of the study.

Anesthesia was efficient with ethyl ether, however other anesthetics should be considered taking into consideration possible interferences in the experiments.

The OHC effect on the diets evaluated after 15 and 43 days, and the mean weights of the groups with proteic and non-proteic diets were significantly different $(p<0.0001)$. In the third evaluation a significant effect of the $\mathrm{CHO}$ addition was observed only in the non-proteic diet group ( $p=0.0104)$.

In the total protein analysis there was a significant effect of the diets only after 43 days $(p<0.0001)$. Diet influenced the mean total protein levels, however $\mathrm{OHC}$ addition did not.

The albumin determination indicated that its mean levels showed the significant effect of the diets after 43 days ( $p=$ $0.0003)$, and the $\mathrm{OHC}$ addition effect was also observed after 43 days ( $p=0.0282)$, only in the non-proteic diet group ( $p=$ 0.0094).

Osteocalcin synthetized by osteoblasts is incorporated to the bone matrix liberating a small fraction in the circulation, and serves as an important marker of bone formation (DELMAS, 
como importante marcador de formação óssea ${ }^{3}$. Não foi observada interferência do $\mathrm{COH}$ no nível de osteocalcina, quando esse foi avaliado em animais nutridos e desnutridos. A osteocalcina tem afinidade pelo cálcio e pela hidroxiapatita não cristalizada servindo, ao lado da fosfatase alcalina, como orientador do grau de atividade osteoblástica ${ }^{2}$.

O exame radiográfico dos animais feito em perfil foi suficiente para avaliar o local da fratura e os aspectos gerais da consolidação óssea observados nos quatro diferentes grupos de animais, conforme o critério de $\mathrm{ARO}{ }^{1}$ et al. (1985). Acreditou-se, porém, que o estudo em anteroposterior, após desarticulação de joelho e tornozelo, poderia dar dados mais significativos do estudo planimétrico.

No estudo densitométrico observou-se serem os animais dos grupos nutridos os detentores de maiores densidades minerais caso sejam comparados com os grupos desnutridos, demonstrando o efeito significativo da dieta $(p=0,0191)$ e a não-significância do $\mathrm{COH}(p=0,9567)$. Na avaliação histomorfométrica da fibrose, tecido cartilagíneo e tecido ósseo, não se observaram diferenças estatisticamente significativas nos animais nutridos e desnutridos com o uso do $\mathrm{COH}$. O efeito significativo da dieta foi verificado quando se comparou a porcentagem de fibrose $(p=0,0024)$ e a de osso $(p=0,0211)$.

Na avaliação laboratorial dos níveis médios de cálcio, não houve diferenças significativas em relação à dieta e ao medicamento. 0 cálcio e o fósforo integrantes do $\mathrm{COH}$ não interferiram durante o experimento.

A complexidade dos fenômenos que cercam a consolidação óssea não permitiu estabelecer com os marcadores do metabolismo ósseo utilizados, o efeito do $\mathrm{COH}$ nos animais nutridos e desnutridos, sobretudo em sua parte orgânica que é a mais importante, a osseína ${ }^{12}$.

A melhor compreensão do mecanismo da consolidação de fraturas, ao lado de análises mais apropriadas da interação dos diferentes componentes orgânicos e inorgânicos do tecido ósseo, certamente possibilita a descoberta de drogas que tenham ação mais determinante no processo de consolidação das fraturas.

\section{CONCLUSÕES}

1) $\mathrm{O} \mathrm{COH}$, na dosagem de $20 \mathrm{mg} / \mathrm{dia}$, administrado via oral, no rato adulto Wistar, com ou sem desnutrição protéica, não apresentou, na avaliação geral, Interferência significativa no processo de consolidação de fraturas experimentais.

2) $\mathrm{O} \mathrm{COH}$ interferiu de maneira significativa na medida planimétrica do calo ósseo nos animais nutridos, e no peso e dosagens de albumina e fosfatase alcalina nos animais desnutridos.
1992). No interference of $\mathrm{OHC}$ was observed at the osteocalcin level, when determined in nourished and undernourished animals. Osteocalcin has affinity with calcium and non-crystalized hydroxyapatite and serves, as the alkaline phosphatase, as a guide for the osteoblastic activity degree (BERNE and LEVI, 1995).

A profile X-ray was sufficient to determine the fracture site and the general aspects of bone consolidation in the four different groups of animals, according to ARO et al. (1985) criteria. The anterior-posterior study after disarticulation of the knee and ankle can provide more significant data of the planimetric study.

In the densitometric study, the nourished animals presented the highest mineral densities when compared with the undernourished groups showing the significant effect of the diet ( $p=0.0191)$ and the non-significance of OHC ( $p=0.9567)$. In the histomorphometric evaluation of fibrosis, cartilaginous and bone tissues, no statistically significant differences were observed in the nourished and undernourished animals after $\mathrm{OHC}$. The significant effect of the diet was observed when fibrosis $(p=0.0024)$ and bone $(p=0.0211)$ percentages were compared.

Concerning the laboratory determination of mean levels of calcium there were not significant differences in relation to diet and medication. Calcium and phosphorus from $\mathrm{OHC}$ did not interfere during the experiment.

The OHC effect on nourished and undernourished animals, mainly on their most important organic part, ossein (SCHMIDT, 1988), could not be established with the bone metabolism markers due to the complexity of the phenomena concerning bone consolidation.

The best comprehension of the fracture consolidation mechanism, in addition to more adequate analyses of the interaction between different organic and inorganic components of the bone tissue, certainly will possibilitate the synthesis of drugs which have a more determinant action on the fracture consolidation process.

\section{CONCLUSIONS}

1) $\mathrm{OHC}, 20 \mathrm{mg} /$ day, orally administered to Wistar adult rats with or without protein malnutrition, did not interfere significantly in the process of consolidating experimental fractures.

2) $\mathrm{OHC}$ interfered significantly in the planimetric determination of the bone callus in nourished animals and in weight and dose of albumin and alkaline phosphatase in undernourished animals. 


\section{REFERÊNCIAS}

1. ARO, H.; EEROLA, E.; AHO, A.J. Determination of callus quantity in 4-week-old fractures of the rat tibia. J. Orthop. Res., v. 3, p. 10108, 1985.

2. BERNE, R.M. ; LEVY, M.N. Fisiologia. 3.ed. Rio de Janeiro : Guanabara Koogan, 1996. Cap. 47: Regulação Endócrina do Metabolismo do Cálcio e do Fosfato, p.823-41.

3. DELMAS, P.D. Clinical use of biochemical markers of bone remodeling in osteoporosis. Bone, v. 13, p. 17-21, 1992.

4. GUARNIERO, R. Estudo da consolidação de fraturas na desnutrição proteica: trabalho experimental em ratos. São Paulo, 1987. 74 p. Tese (Doutorado). Faculdade de Medicina, Universidade de São Paulo.

5. GUARNIERO, R.; BARROS, T. E. P.; ZERBINI, C. A. F.; RODRIGUES, C.J. J.; PEDRINELLI CORSATO, M.; REIS, P. R. Estúdio experimental de la consolidación de fracturas em la desnutrición protéica. Utilización de calcitonina em ratas desnutridas. Rev Esp Cir Osteoart, v.30, p.21-27, 1995

6. HEARD, C. W.; GRIFFITH, R. B.; DUDRICK, S. J. The effects of nutrition on fracture healing. Orthopaedic Trans. v.6, p. 102, 1982b.
7. HEARD, C. W.; GRIFFITH, R. B.; DUDRICK, S. J. The positive impact of nutritional support on fracture healing. In: Abstracts VI Aspen Congress, San Francisco, Califórnia, 1982a.

8. LI, J.; LEE, W. S.; CHOW, S. Y.; WOODBURY, D. M. Adaptation of cancellous bone to aging and immobilization in the adult rat: a single photon absorptiometry and histomorphometry and recovery. Anat Res. v.227, p. 12-24, 1990.

9. MAEDA, H.; KIMMEL, D.B.; LANE, N.; RAAB, D. The musculoskeletal response to immobilization and recovery. Bone, v.14, p. 153-59, 1993.

10. OTTO, T. E.; PATKA, P.; HAARMAN, H. J. Closed fracture healing: a rat model. Eur. Surg. Res. V. 27, p. 277-284, 1995.

11. PARK E. A. The imprinting of nutritional disturbances on the growing bone. Pediatrics, v. 33, p. 815-62, 1964.

12. SCHMIDT, K.H. ; WÖRNER, U.M. ; BUCK, H.J. Examination of new bone growth on aluminium oxide implant contact surfaces after oral administration of ossein-hydroxyapatite compound to rats. Curr. Med. Res. Opin., v.11, n.2, p.107-115, 1988.

13. URIST, M. R.; McLEAN, F. C. Bone repair in rats with multiple fractures. Am. J. of Surgery, v. 15, p. 685-95, 1950. 